\title{
RETROSPECTIVE STUDY ON PORCINE CIRCOVIRUS-2 BY NESTED PCR AND REAL TIME PCR IN ARCHIVED TISSUES FROM 1978 IN BRAZIL
}

\author{
Fernanda Miquelitto Figueira da Silva ${ }^{1}$, Abelardo Silva Júnior ${ }^{2}$, Ethel Fernandes de Oliveira Peternelli ${ }^{1}$, Vinícius Winter \\ Viana $^{2}$, Orlando Chiarelli Neto ${ }^{1}$, Juliana Lopes Rangel Fietto ${ }^{1}$, Marlene Izabel Vargas², Luís Augusto Nero², Márcia \\ Rogéria de Almeida ${ }^{{ }^{*}}$
}

${ }^{1}$ Departamento de Bioquímica e Biologia Molecular, Universidade Federal de Viçosa, Viçosa, MG, Brasil; ${ }^{2}$ Departamento de Veterinária, Universidade Federal de Viçosa, Viçosa, MG, Brasil.

Submitted: September 19, 2010; Returned to authors for corrections: October 21, 2010; Approved: March 14, 2011.

\begin{abstract}
Porcine circovirus-2 (PCV-2) infection is currently considered an important disease of swine. The pathogenic agent was first described in Brazil in 2000. This study detected the PCV-2 DNA in four Brazilian pig tissues collected between 1978 and 1979. This observation is the oldest description of this virus in Brazil.
\end{abstract}

Key words: PCV-2, retrospective study, Brazil.

Porcine circovirus (PCV) is a member of Circoviridae family along with other animal circoviruses, such as psittacine beak and feather disease virus and chicken anemia virus (4). $\mathrm{PCV}$ is one of the smallest viruses that replicates autonomously in mammalian cells and it is characterized as an icosahedral non-enveloped virus with $17 \mathrm{~nm}$ containing a single-stranded circular DNA genome with about $1.76 \mathrm{~kb}(9,22)$. Currently, two species of PCV are recognized, PCV-1 and PCV-2. PCV-1 was originally identified in the porcine kidney cell line (PK15) (22) and is being considered a nonpathogenic virus. PCV-2 is associated with postweaning multisystemic wasting syndrome (PMWS) $(3,8,10)$.

PCV-2 is usually associated to porcine dermatitis and nephropathy syndrome (PDNS), abortions, reproductive failure in sows, respiratory porcine disease complex and PMWS (13, 17, 21, 23). The association of PCV-2 with any of these diseases is currently named as PCV-2 associated diseases (PCVAD). PCVAD are considered as important swine diseases causing significant economic losses in swine worldwide industry $(2,11,18)$.

PCV-2 infection was first described in Canada in 1991 associated to PMWS (7). This agent has a worldwide distribution (1), including Brazil, where it was first described in 2000 (5). Since the first record, retrospective studies with stored tissues have been conducted in several countries and used techniques such as in situ hybridization (ISH), immunohistochemistry using monoclonal antibody or nestedPCR. Considering these studies, PCV-2 was detected in Spain in lung and lymph node stored tissues from 1986 (19), in Thailand in tonsil lymph nodes and spleen from 1993 (12), even in Brazil, in the kidney, liver and lymph nodes from 1988 (6).

\footnotetext{
*Corresponding Author. Mailing address: Laboratório de Infectologia Molecular Animal - Instituto de Biotecnologia Aplicada à Agropecuária - Universidade Federal de Viçosa - Viçosa - Minas Gerais - 36570-000.; Tel.: + 553138992911 Fax: + 5531 3899 2864.; E-mail: marcia@ufv.br
} 
The aim of this study was to conduct a retrospective research of PCV-2 DNA in Brazilian sample tissues collected in 1978 and 1979, stored in blocks of paraffin for histological analyses.

We used the quantitative real time polymerase chain reaction (qPCR), which is an extremely useful tool to clarify the pathogenic action of viral agents in animal infectious diseases. This technique, qPCR, when compared to other methodologies, such as, conventional PCR and in situ hybridization allowing an increase in the detection frequency of viral agents and becoming an interesting technique for pathogen diagnosis (15).

Twelve histological sections of lung, renal, liver and lymphoid tissues stored in paraffin blocks from 1978 and 1979 were selected considering the presence of suspected lesions caused by PCV-2. Information about clinical signs, macroscopic and microscopic animal lesions were collected from the log file of the protocols in the tissue collections from the Histopathology Laboratory from Veterinary Department from the Federal University of Viçosa, located in Viçosa, Minas Gerais, Brazil.

The $10 \mu \mathrm{m}$ selected histological sections were treated with xylol to remove the paraffin, and then centrifuged and washed with ethanol (100\%). After the supernatants were discarded, the DNA from tissue was extracted using the WIZARD SV Genomic Purification System kit (Promega, Madison, USA). The DNAs were quantified by spectrophotometric assays.

A full length PCV-2 genome (GenBank access number: DQ364560) cloned into pGEM vector (Promega, Madison, USA) and propagated in DH5 $\alpha$ Escherichia coli cells was used as internal standard for PCV-2 DNA quantification assays. The plasmid was purified using the commercial kit Wizard Plus SV Minipreps DNA Purification System (PROMEGA, Madison, USA), and quantified by spectrophotometry. The primers and probe used for qPCR were described by Olvera et al. (16). The optimized reactions contained 200nM of each primers, $200 \mathrm{nM}$ probe, $12.5 \mu \mathrm{L}$ TaqMan® universal master mix (Applied Biosystems, Foster City, USA) and 300ng DNA template.
Autoclaved ultra purified water was added to achieve the final volume of $25 \mu \mathrm{L}$. Amplifications were carried out under universal cycling conditions $\left(10 \mathrm{~min}\right.$ at $95^{\circ} \mathrm{C}, 2 \mathrm{~min}$ at $50^{\circ} \mathrm{C}, 40$ cycles of $15 \mathrm{sec}$ at $95^{\circ} \mathrm{C}$, and $1 \mathrm{~min}$ at $60^{\circ} \mathrm{C}$ ). The ABI Prism 7.500 detection software generated a standard curve with the threshold cycle $(\mathrm{Ct})$ values of the 10-fold dilutions of PCV-2 plasmid (from $10^{9}$ to $10^{1}$ copies of the viral genome). Positive and negative reference samples were tested along with the unknown samples in each run. The detection software calculated the correlation PCV-2 copy number of the samples considering the standard curve.

Alternatively, the samples was tested using the nested PCR previously described by Lyoo et al. (14). The nested PCR products were purified and sequenced by the commercial Macrogen facility (Macrogen, Seoul, Korea). The ORF2 partial sequences were compared to sequences of PCV-2 in GenBank through the Basic Local Alignment Search Tool (BLAST) (http://www.ncbi.nlm.nih.gov/).

Four of the tested sample tissues showed positive results for PCV-2 DNA by the qPCR technique (Table 1). Positive samples were from the 1978 stored tissues, and presented numbers of genome copies between 1.08 and $2.00\left(\log _{10}\right.$ values) in 300ng of DNA (Figure 1). The sensitivity can be attributed to the degree of conservation of the samples because they were stored in paraffin for nearly 20 years and the quality of DNA obtained was not satisfactory. It was not possible to perform immunohistochemical tests because of the degree of deterioration of the samples.

The same samples that presented positive results for PCV2 DNA by qPCR and nested PCR showed typical lesions of viral infection (Table 1). The observed lesions were compatible with PCV-2 infection, and were characterized by the presence of interstitial pneumonia with mixed inflammatory cell infiltrate. These characteristic lesions associated with the detection of the PCV-2 DNA diagnosis support the hypothesis of PCV-2 respiratory infection. The nucleotide analysis showed that the sequences obtained in this study have $99-100 \%$ identity with other sequences of PCV-2 in GenBank (Table 1). 
Table 1. Description of samples stored in paraffin blocks.

\begin{tabular}{|c|c|c|c|c|c|c|}
\hline Year & $\begin{array}{c}\text { Results of } \\
\text { nested-PCR }\end{array}$ & $\begin{array}{l}\text { Results of qPCR } \\
\left(\log _{10} \text { values }\right)\end{array}$ & Identity & Tissues & Macroscopic/microscopic lesions & Clinical sings \\
\hline 1978 & - & Negative & - & Lung & Pneumonia/interstitial pneumonia & Respitarory disease \\
\hline 1978 & + & 2.00 & $99 \%$ & Lung & Pneumonia/interstitial pneumonia & Respitarory disease \\
\hline 1979 & - & Negative & - & Kidney & Not lesions associated disease & Wasting \\
\hline 1979 & - & Negative & - & Liver & $\begin{array}{c}\text { Increase in volume/periportal } \\
\text { hepatitis }\end{array}$ & Wasting \\
\hline 1979 & - & Negative & - & Lymph nodes & $\begin{array}{c}\text { Not macroscopic and microscopic } \\
\text { lesions }\end{array}$ & $\begin{array}{l}\text { Not clinical sings associated } \\
\text { disease }\end{array}$ \\
\hline 1979 & - & Negative & - & Lymph nodes & $\begin{array}{l}\text { Not macroscopic and microscopic } \\
\text { lesions }\end{array}$ & $\begin{array}{l}\text { Not clinical sings associated } \\
\text { disease }\end{array}$ \\
\hline 1979 & - & Negative & - & Lymph nodes & $\begin{array}{c}\text { Not macroscopic and microscopic } \\
\text { lesions }\end{array}$ & $\begin{array}{c}\text { Not clinical sings associated } \\
\text { disease }\end{array}$ \\
\hline 1979 & + & 1.11 & $99 \%$ & Lung & Pneumonia/interstitial pneumonia & Respitarory disease \\
\hline 1979 & + & 1.44 & $100 \%$ & Lung & $\begin{array}{l}\text { Pneumonia/interstitial pneumonia } \\
\text { Pneumonia/ interstitial pneumonia }\end{array}$ & Respitarory disease \\
\hline 1979 & + & 1.50 & $100 \%$ & Lung & Pneumonia/interstitial pneumonia & Respitarory disease \\
\hline 1979 & - & Negative & - & $*$ & $*$ & $*$ \\
\hline 1979 & - & Negative & - & $*$ & $*$ & $*$ \\
\hline
\end{tabular}
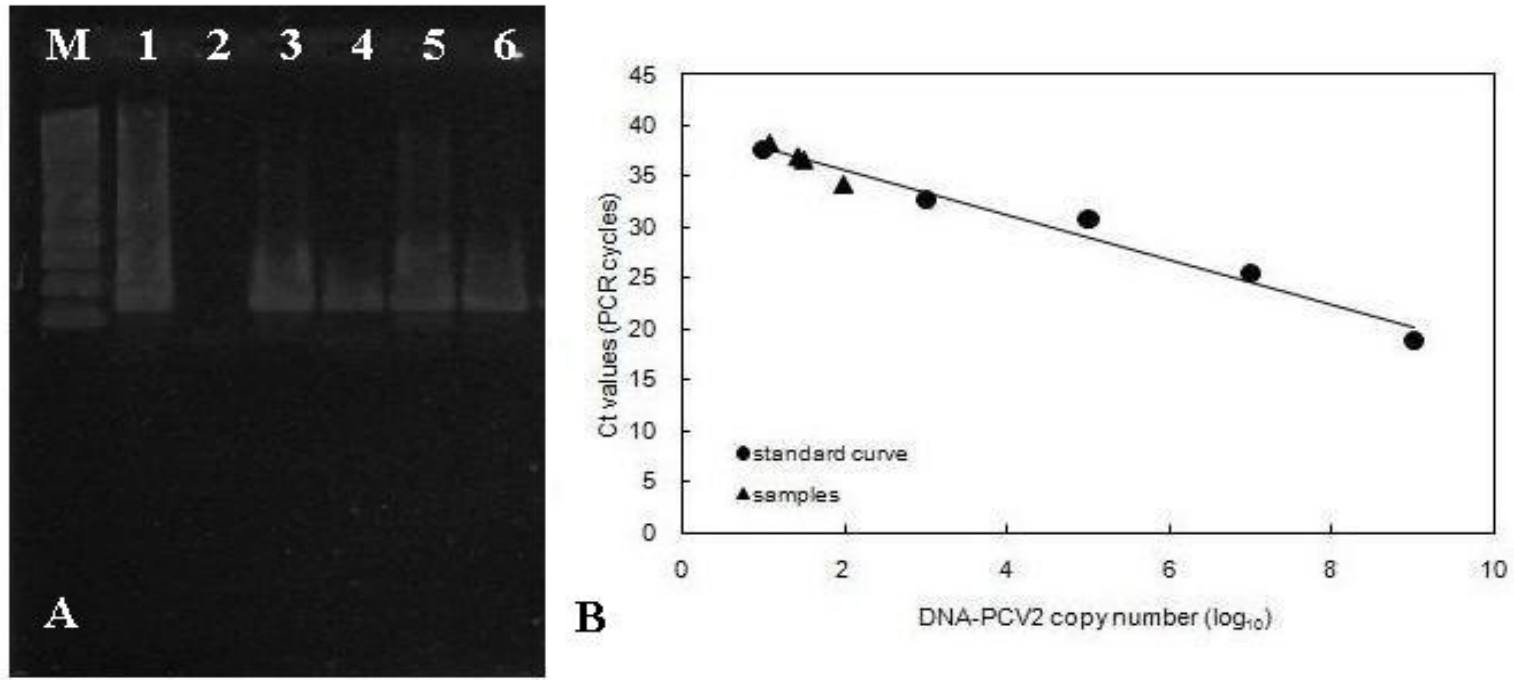

Figure 1. Detection of Porcine circovirus-2 (PCV-2) in brazilians archived porcine tissues. (A) Nested PCR products obtained from positive tissues samples. Lane M: molecular size standard (Generuler 1kb DNA ladder; Fermentas, Vilnius, Lithuania). Lane 1: positive control. Lane 2: negative control. Lanes 3-6: nested PCR products from archived porcine tissues (360bp). (B) Detection of DNA viral by quantitative real time PCR. Average threshold cycle $(\mathrm{Ct})$ values plotted against DNA PCV2 copy, number of positive samples and standard curve. The standard curve and the calculated efficiency for this assay were $y=-4,425 x+42,361$ and $98,05 \%$, respectively. 
These results indicate the presence of PCV-2 in Brazil since 1978, despite the fact that this viral agent became significant for world swine production only in 1997 when the clinical signs were experimentally reproduced by Clark (7). The detection of PCV-2 in stored tissues from years before 1997 was also observed in other countries $(12,19)$, even in Brazil (6). According to Segalés et al. (20) several tissue samples could be associated to PCV-2 after the description of PMWS, indicating the presence of this pathogen since 1969. However, these works have not classified the genotype of PCV-2.

The detection of PCV-2 in stored tissues from 1978 by qPCR and nested PCR shows the presence of this viral agent in porcine production before its first record in Brazil, which occurred in 2000. This result indicates that the evolution of PCV-2 in Brazil may have occurred since this period. Furthermore, the utilization of qPCR in a retrospective study opened a new way to investigate the evolution of PCV-2 in a worldwide perspective.

\section{ACKNOWLEDGEMENTS}

This research was supported by grants from FAPEMIG and CNPq.

\section{REFERENCES}

1. Allan, G. M.; Ellis, J. A. (2000). Porcine circoviruses: a review. J. Vet. Diagn. Invest. 12(1), 3-14.

2. Allan, G. M.; Kennedy, S.; McNeilly, F.; Foster, J. C.; Ellis, J. A.; Krakowka, S. J.; Meehan, B. M.; Adair, B. M. (1999). Experimental reproduction of severe wasting disease by co-infection of pigs with porcine circovirus and porcine parvovirus. J. Comp. Pathol. 121(1), 111.

3. Allan, G. M.; McNeilly, F.; Kennedy, S.; Daft, B.; Clarke, E. G.; Ellis, J. A.; Haines, D. M.; Meehan, B. M.; Adair, B. M. (1998). Isolation of porcine circovirus-like viruses from pigs with a wasting disease in the USA and Europe. J. Vet. Diagn. Invest. 10(1), 3-10.

4. Bassami, M. R.; Berryman, D.; Wilcox, G. E.; Raidal, S. R. (1998) Psittacine beak and feather disease virus nucleotide sequence analysis and its relationship to porcine circovirus, plant circoviruses, and chicken anaemia virus. Virology 249(2), 453-459.

5. Ciacci-zanella, J.R.; Mores, N. (2003). Diagnostic of postweaning multisystemic wasting syndrome (PMWS) in swine in Brazil caused by porcine circovirus type 2 (PCV2). Braz. J. Vet. An. Sci. 55, 522-527.

6. Ciacci-zanella, J.R.; Mores, N.; Simom, N.L.; Oliveira, S.R.; Gava, D. (2006). Identification of porcine circovirus type 2 by polymerase chain reaction and immunohistochemistry on archived porcine tissues since 1988 in Brazil. Ciência Rural 36, 1480-1485.

7. Clark, E.G. (1997). Post-weaning wasting syndrome. Proc. Am. Assoc. Swine Prac. 28, 449-501.

8. Ellis, J.; Hassard, L.; Clark, E.; Harding, J.; Allan, G.; Willson, P.; Strokappe, J.; Martin, K.; McNeilly, F.; Meehan, B.; Todd, D.; Haines, D. (1998). Isolation of circovirus from lesions of pigs with postweaning multisystemic wasting syndrome. Can. Vet. J. 39(1), 44-51.

9. Hamel, A.L.; Lin, L.L.; Nayar, G.P. (1998). Nucleotide sequence of porcine circovirus associated with postweaning multisystemic wasting syndrome in pigs. J. Virol. 72(6), 5262-5267.

10. Harding, J.C.; Clark, E.G. (1997). Recognizing and diagnosing postweaning multisystemic wasting syndrome (PMWS). J. Swine Heal. Prod. 5, 201-203.

11. Hasslung, F.C.; Berg, M.; Allan, G.M.; Meehan, B.M.; McNeilly, F.; Fossum, C. (2003). Identification of a sequence from the genome of porcine circovirus type 2 with an inhibitory effect on IFN-alpha production by porcine PBMCs. J. Gen. Virol. 84(11), 2937-2945.

12. Kiatipattanasakul-Banlunara, W.; Tantilertcharoen, R.; Suzuki, K.; Albarenque, S. M.; Thanawongnuwech, R.; Nakayama, H.; Doi, K. (2002). Detection of porcine circovirus 2 (PCV-2) DNA by nested PCR from formalin-fixed tissues of post-weaning multisystemic wasting syndrome (PMWS) pigs in Thailand. J. Vet. Med. Sci. 64(5), 449-452.

13. Kim, J.; Chung, H. K.; Jung, T.; Cho, W. S.; Choi, C.; Chae, C. (2002). Postweaning multisystemic wasting syndrome of pigs in Korea: prevalence, microscopic lesions and coexisting microorganisms. J. Vet. Med. Sci. 64(1), 57-62.

14. Lyoo, K. S.; Kim, H. B.; Joo, H. S. (2008). Evaluation of a nested polymerase chain reaction assay to differentiate between two genotypes of Porcine circovirus-2. J. Vet. Diagn. Invest. 20(3), 283-288.

15. Mackay, I. M.; Arden, K. E.; Nitsche, A. (2002). Real-time PCR in virology. Nucleic Acids Res. 30(6), 1292-1305.

16. Olvera, A.; Sibila, M.; Calsamiglia, M.; Segales, J.; Domingo, M. (2004). Comparison of porcine circovirus type 2 load in serum quantified by a real time PCR in postweaning multisystemic wasting syndrome and porcine dermatitis and nephropathy syndrome naturally affected pigs. $J$. Virol. Methods 117(1), 75-80.

17. Park, J. S.; Kim, J.; Ha, Y.; Jung, K.; Choi, C.; Lim, J. K.; Kim, S. H.; Chae, C. (2005). Birth abnormalities in pregnant sows infected intranasally with porcine circovirus 2. J. Comp. Pathol. 132(2-3), 139144. 
18. Rodriguez-Arrioja, G. M.; Segales, J.; Calsamiglia, M.; Resendes, A. R.; Balasch, M.; Plana-Duran, J.; Casal, J.; Domingo, M. (2002). Dynamics of porcine circovirus type 2 infection in a herd of pigs with postweaning multisystemic wasting syndrome. Am. J. Vet. Res. 63(3), 354-357.

19. Rodriguez-Arrioja, G. M.; Segales, J.; Rosell, C.; Rovira, A.; Pujols, J.; Plana-Duran, J.; Domingo, M. (2003). Retrospective study on porcine circovirus type 2 infection in pigs from 1985 to 1997 in Spain. J. Vet. Med. B. Infect. Dis. Vet. Public Health 50(2), 99-101.

20. Segalés, J.; Allan, G. M.; Domingo, M. (2005). Porcine circovirus diseases. Anim. Health Res. Rev. 6(2), 119-142.

21. Thibault, S.; Drolet, R.; Germain, M. C.; D'Allaire, S.; Larochelle, R.;
Magar, R. (1998). Cutaneous and systemic necrotizing vasculitis in swine. Vet. Pathol. 35(2), 108-116.

22. Tischer, I.; Gelderblom, H.; Vettermann, W.; Koch, M. A. (1982). A very small porcine virus with circular single-stranded DNA. Nature 295(5844), 64-66.

23. West, K. H.; Bystrom, J. M.; Wojnarowicz, C.; Shantz, N.; Jacobson, M.; Allan, G. M.; Haines, D. M.; Clark, E. G.; Krakowka, S.; McNeilly, F.; Konoby, C.; Martin, K.; Ellis, J. A. (1999). Myocarditis and abortion associated with intrauterine infection of sows with porcine circovirus 2 . J. Vet. Diagn. Invest. 11(6), 530-532. 